\title{
LINC01565 wt Allele
}

National Cancer Institute

\section{Source}

National Cancer Institute. LINC01565 wt Allele. NCI Thesaurus. Code C54280.

Human LINC01565 wild-type allele is located within 3q21.3 and is approximately $4 \mathrm{~kb}$ in length. This allele, which encodes protein GR6 and long intergenic non-protein coding RNA 1565, is putatively involved in the suppression of cell growth. LINC01565 gene dysfunction is associated with several types of cancer including acute myeloid monocytic leukemia and colorectal cancer. 